\title{
Shift from native mussels to alien oysters: Differential effects of ecosystem engineers
}

\author{
Judith Kochmann ${ }^{\text {a,b }}$, Christian Buschbaum ${ }^{\text {a }}$, Nils Volkenborn ${ }^{\text {a }}$, Karsten Reise ${ }^{\text {a,* }}$ \\ a Alfred Wegener Institute for Polar and Marine Research, Wadden Sea Station Sylt, Hafenstrasse 43, D-25992 List, Germany \\ b University of Southern Denmark, Institute of Biology, Campusvej 55, 5230 Odense M, Denmark
}

\section{A R T I C L E I N F O}

\section{Article history:}

Received 15 February 2008

Received in revised form 16 April 2008

Accepted 28 May 2008

\section{Keywords:}

Biogenic habitat

Crassostrea gigas

intertidal flat

macrozoobenthos

Mytilus edulis

Wadden Sea

\begin{abstract}
A B S T R A C T
Blue mussel (Mytilus edulis) beds in the intertidal Wadden Sea (coastal North Sea) have been replaced by introduced Pacific oysters (Crassostrea gigas). To test the effects of these habitat-generating suspension feeders on associated macrozoobenthos, a field experiment was designed. Circular plots ('rings') were composed either of oysters, mussels, both together or none at all. These four treatments were arranged in June 2006 in 5 blocks along low tide line. Rings enclose $3 \mathrm{~m}^{2}$ of bare muddy sand surrounded by a 1-m-wide belt $\left(10 \mathrm{~m}^{2}\right)$ of the densely packed epibenthic suspension feeders. Sediment, infauna, mobile epifauna and settling sessile epifauna were sampled. Epibenthic suspension feeders caused an accumulation of fine particles and organic content in the sediment. This was particularly true for mixed treatments indicating interactive effects of both bivalves on sediment characteristics. Mussels caused finer sediment grain-size composition compared to bare sediment. This did not occur among oysters but both bivalves increased organic content. The presence of mussels and oysters increased the abundance of infaunal and epibenthic mobile species differently. The polychaete Lanice conchilega was more abundant on oyster rings and the oligochaete Tubificoides benedeni on mussel rings. Densities of juvenile shore crabs Carcinus maenas and young periwinkles Littorina littorea ( $<10 \mathrm{~mm}$ shell height) were higher on mussel rings; while abundance of L. littorea $\geq 10 \mathrm{~mm}$ shell height was higher on oyster rings. Juveniles of the barnacle Elminius modestus and of mussels showed no preference while oyster spat preferentially settled on conspecifics. We conclude that a shift in dominance from mussels to oysters alters habitat structures which entail differential abundances of associated organisms. This exchange of suspension feeder species is not neutral to community structure because resident mussels and alien oysters function differently as ecosystem engineers.
\end{abstract}

(c) 2008 Elsevier B.V. All rights reserved.

\section{Introduction}

The concept of ecosystem engineers focuses on habitat structuring organisms (Jones et al., 1994). They affect biological traits by profound architectural changes in the environment. In marine soft-sediments this has been described for e.g. lugworms (Volkenborn and Reise, 2006), sand masons (Rabaut et al., 2007), mussels (Ragnarsson and Raffaelli, 1999) and oysters (Lenihan, 1999). Such engineers may differentially inhibit or facilitate other organisms, provide opportunities for novel niches and the differentiation of existing ones, and may alter the structure of food webs (Buschbaum et al., 2006; Diederich, 2006; Reise, 2002). Habitat modifications are also essential when evaluating the role of alien species with their effects on resident populations (Crooks, 2002; Cuddington and Hastings, 2004; Buschbaum et al., 2006; Thieltges et al., 2006; Wallentinus and Nyberg, 2007).

In the Northern Wadden Sea, the Pacific oyster Crassostrea gigas (Thunberg) plays a fundamental role as an invasive ecosystem engineer. Near the island of Sylt regular introductions of this oyster commenced in 1986 for oyster farming, and natural spread by larvae

\footnotetext{
* Corresponding author. Tel.: +49 4651956 0; fax: +49 4651956200.

E-mail address: Karsten.Reise@awi.de (K. Reise).
}

to mussel beds was observed subsequently (Reise, 1998). Anomalously high water temperatures during spawning season in summer, mild winters, high recruitment success and positive feedback in settlement facilitated the development of a $C$. gigas population, while recruitment repeatedly failed in Mytilus edulis L. (Diederich et al., 2005; Nehls et al., 2006). Mussels are increasingly overgrown and almost all existing intertidal mussel beds adjacent to the oyster farm have turned into oyster reefs since 2005. It is expected that mussels and oysters will coexist in dense aggregations forming compact reefs (Diederich, 2005). However, their relative proportions over a range of habitats cannot yet be foreseen.

This shift in dominance from mussels to oysters could have (a) topdown effects on phytoplankton, (b) bottom-up effects on shellfish predators and parasites, and (c) habitat effects on organisms dwelling within beds of mussels or reefs of oysters. To investigate the habitat effects, a large-scale field experiment was designed to mimic effects of mussel beds, mixed beds and oyster reefs on associated organisms. Against the null-hypothesis that a reversal of roles in dominant suspension feeders will be neutral to other macrozoobenthos, we test for abundant taxa of the infauna, mobile epifauna and settling sessile epifauna whether there are losers or winners when dominance shifts from mussels to oysters. 


\section{Materials and methods}

\subsection{Study site}

A large-scale field experiment was set up in the lower intertidal zone of the outer Königshafen, which is a tidal embayment at the northern end of the island of Sylt (North Sea, Germany, $55^{\circ} 04^{\prime} \mathrm{N}$; $08^{\circ} 26^{\prime} \mathrm{E}$; Fig. 1). This embayment is part of the List tidal basin $\left(404 \mathrm{~km}^{2}\right)$, connected to the North Sea through a narrow tidal inlet of $2.8 \mathrm{~km}$ width. Intertidal flats are dominated by sand and make up $159 \mathrm{~km}^{2}$ of the area. Epibenthic mussel beds covered $1 \%$ of the basin intertidal flats in the past but have been largely overgrown by Pacific oysters during the last decade (Diederich et al., 2005; Nehls et al., 2006). Presently, $0.1 \mathrm{~km}^{2}$ of the Königshafen are covered by mixed mussel and oyster beds (personal comm. by T. Dolch).

Sediment at the experimental site mainly consists of medium sand (mean grain size $254 \mu \mathrm{m}$ ) and shell gravel (Austen, 1994). This site was chosen because mussel beds occurred along low tide line (Reise et al., 1994) until ice scoured them away in the winter 1995/96 (Strasser et al., 2001), indicating potentially suitable conditions for dense aggregations of suspension feeders. Tides are semi-diurnal and mean tidal range is $1.8 \mathrm{~m}$. Emersion time was 0 - $3 \mathrm{~h}$ per tidal cycle. Salinity ranges between 31 in summer and 28 in winter. Mean monthly water temperature varied between $19.5^{\circ} \mathrm{C}$ in August and $3.5^{\circ} \mathrm{C}$ in February. Further details on the List tidal basin are given in Gätje and Reise (1998).

\subsection{Experimental design}

During May/June 2006, Pacific oysters (Crassostrea gigas) and blue mussels (Mytilus edulis) taken from natural beds (arrows in Fig. 1) were arranged parallel to low tide line (Fig. 2). Before transplantation bivalves were rinsed several times with seawater to wash off loose material. The experimental set-up was a randomized block-design, consisting of 5 blocks over a distance of $110 \mathrm{~m}$ (Fig. 2). Each block consisted of 4 experimental plots differing in treatment: plot covered with oysters (C), plot covered with mussels (M), plot covered with oysters and mussels $(\mathrm{CM})$ and bare sediment $(\mathrm{S})$. Plots were designed as rings enclosing $3 \mathrm{~m}^{2}$ of bare sediment surrounded by a $1 \mathrm{~m}$ wide belt $\left(10 \mathrm{~m}^{2}\right)$ of the densely packed epibenthic suspension feeders (Fig. 3). On each plot the number of mussels and oysters was approximated to natural mussel beds with 2000 - 4000 mussels per $1 \mathrm{~m}^{2}$ (Buschbaum and Saier, 2001) and oyster beds in the area as of 2006 with about 1000 oysters per $1 \mathrm{~m}^{2}$ (Nehls et al., 2006; own estimate). This corresponds with biovolumes (bivalves with shells closed and attached barnacles) per $1 \mathrm{~m}^{2}$ of sediment surface (Fig. 3). Epibenthic suspension feeders were almost absent on bare sediment plots. The experimental design allowed for testing effects of mussels and oysters on associated benthos and on test organisms placed into the centre of the rings. Results of the latter are reported by Buschbaum et al. (in prep.) and Thieltges et al. (submitted). We here focus on sediment change and associated species at the belts of the suspension feeder rings compared to bare sediment rings.

\subsection{Sampling of sediment, infauna and mobile and recruiting epibenthic macrofauna}

Samples were taken at random from belts of experimental plots but excluding positions $<20 \mathrm{~cm}$ from edges. To facilitate comparison of abundances, we extrapolated individual numbers of infauna, mobile and recruiting species to $1 \mathrm{~m}^{2}$ although this may not be appropriate for the Standard Error.

\subsubsection{Sediment analysis}

To analyze particulate organic matter (POM), 5 samples of $10 \mathrm{~cm}^{3}$ of surface sediment (upper $5 \mathrm{~cm}$ ) were taken from each plot between suspension feeders in April 2007, dried at $60{ }^{\circ} \mathrm{C}$ for $5 \mathrm{~d}$, combusted at $520^{\circ} \mathrm{C}$ for $8 \mathrm{~h}$ and organic content was calculated as weight loss from dried to ash weight of the sediment. For grain size analysis, 5 surface sediment samples (upper $2 \mathrm{~cm}$ ) were taken from each plot and pooled.

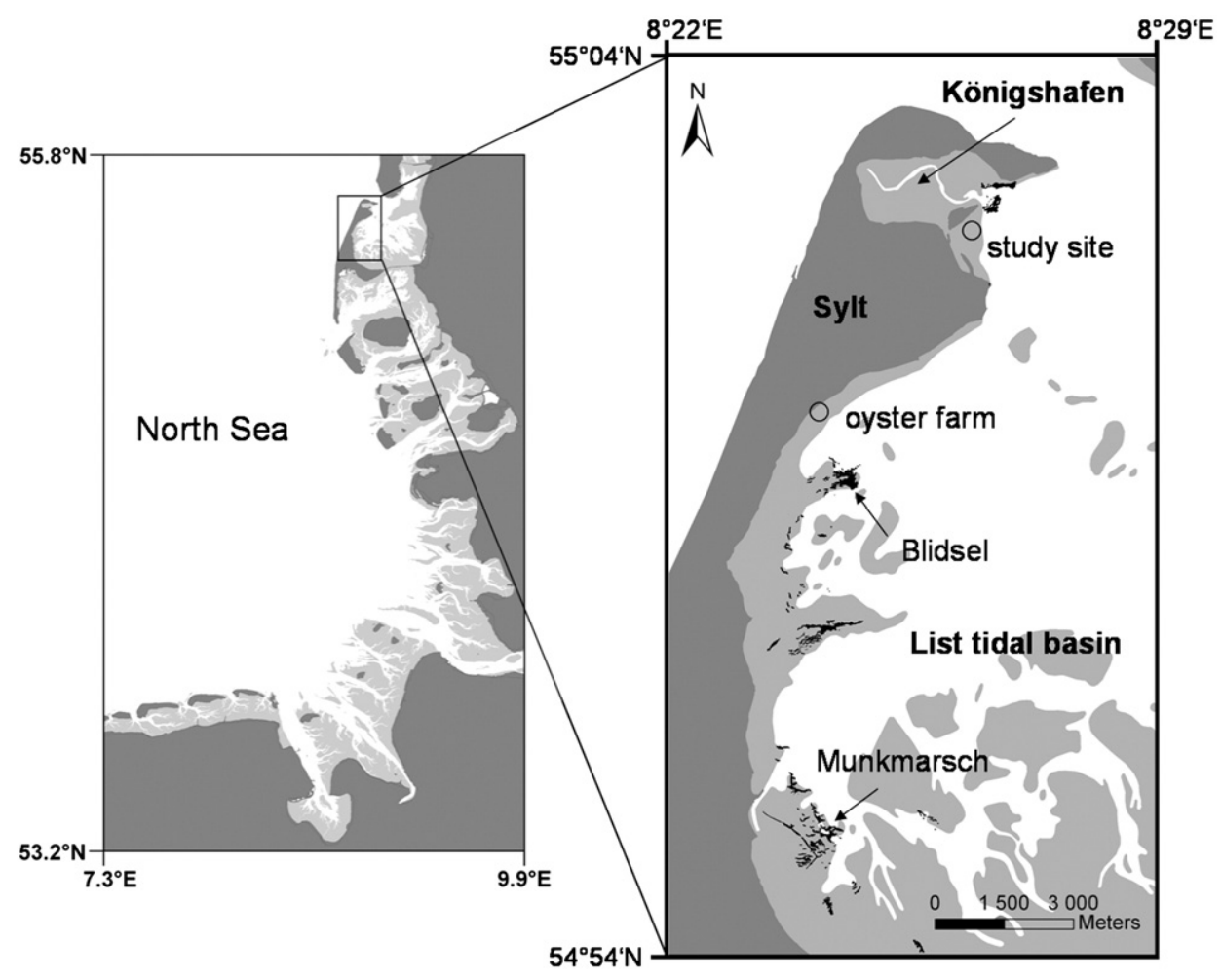

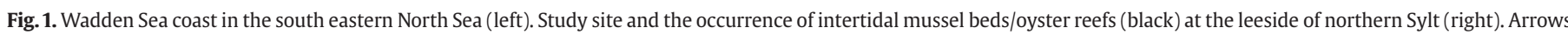
point to source areas of mussels (Munkmarsch) and oysters (Blidsel). Light shading indicates intertidal flats, dark shading indicates land. 


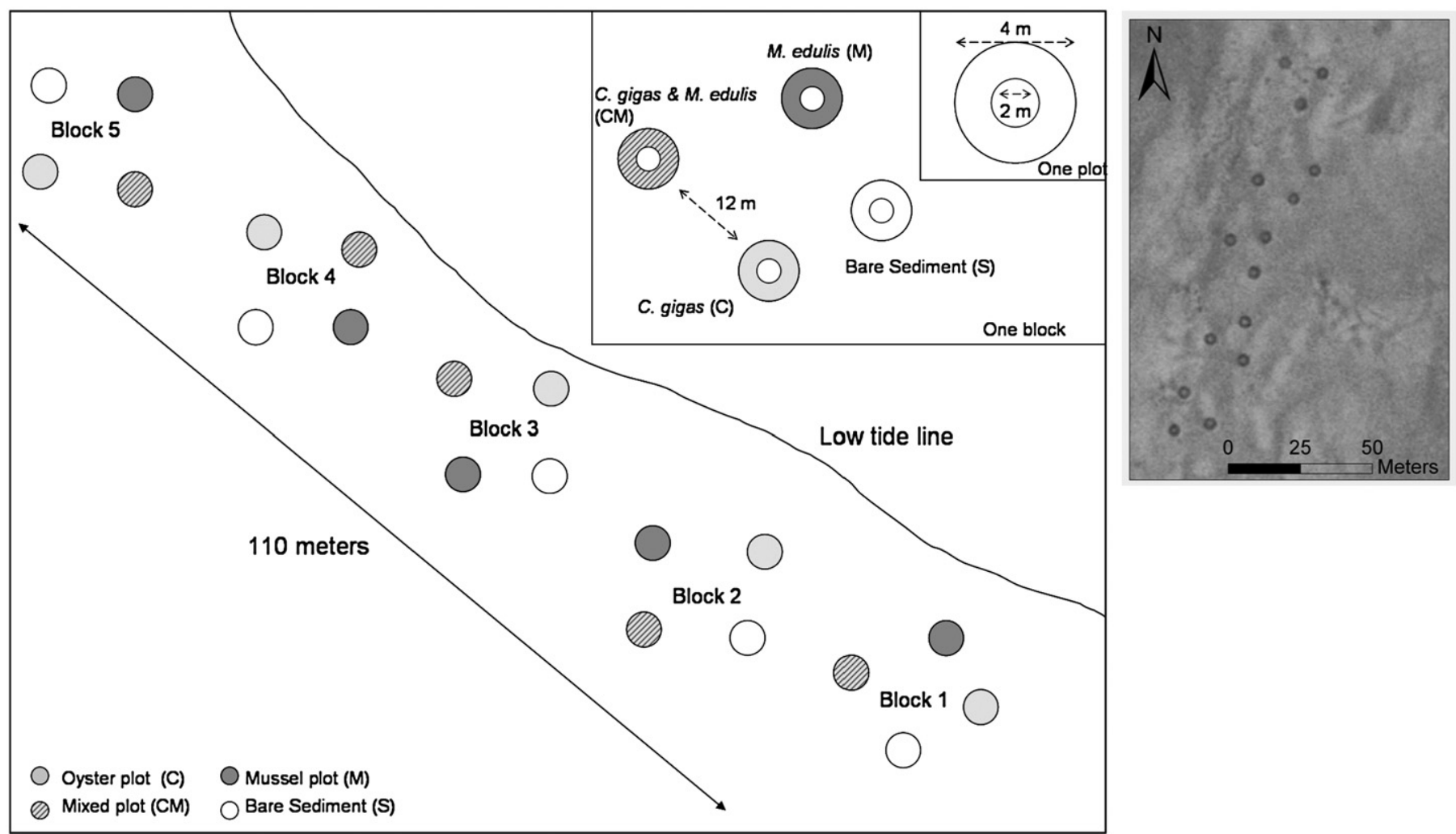

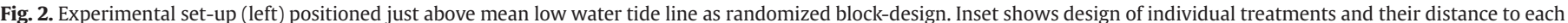
other. Aerial photograph (right) shows the suspension feeder rings contrasting with bare sediment in August 2006.

Subsamples of 8 - $10 \mathrm{~g}$ were treated with acetic acid and hydrogen peroxide $\mathrm{H}_{2} \mathrm{O}_{2}$ (6\%) to remove organic components. Grain size was measured with CILAS 1180 Laser particle analyzer and the results were further evaluated with the statistic package GRADISTAT (Version 4.0, Blott and Pye, 2001).

\subsubsection{Infauna}

To analyze effects of mussels and oysters on infauna, experimental rings were sampled in autumn (October 2006, 4 months after start) and spring (March 2007, 9 months after start). Autumn sampling was focused on small and large macrofauna (>250 $\mu \mathrm{m})$, while spring sampling was focused only on large macrofauna $(>1000 \mu \mathrm{m})$. The former was chosen to include potential summer recruitment after the experiment had commenced, and the latter to address differential survival or choice to stay in adult specimen.
In October 2006 samples of $10 \mathrm{~cm}^{2}$ and $5 \mathrm{~cm}$ depth were randomly taken with a tube corer (diameter of $3.6 \mathrm{~cm}$ ) between suspension feeders to analyze infaunal assemblages. Previous work on soft-bottom mussel beds (Kostylev and Erlandsson, 2001; Commito et al., 2006) has shown the importance of small to intermediate spatial scales. However, we decided to pool 5 replicate samples to $250 \mathrm{~cm}^{3}$ in total for each experimental plot as it seemed to be the most adequate method to level out small-scale patchiness of infauna. Species retained on a $250 \mu \mathrm{m}$ mesh were identified to species level and counted. In March 2007 a box corer of $200 \mathrm{~cm}^{2}$ and a sampling depth of approximately $15 \mathrm{~cm}$ were used and specimen retained on a $1 \mathrm{~mm}$ mesh were identified and counted. Additionally, tube caps of Lanice conchilega (Pallas) were counted on 4 randomly chosen squares of $625 \mathrm{~cm}^{2}$ on each experimental plot. This method enables a representative density assessment of $L$. conchilega (van Hoey et al., 2006).
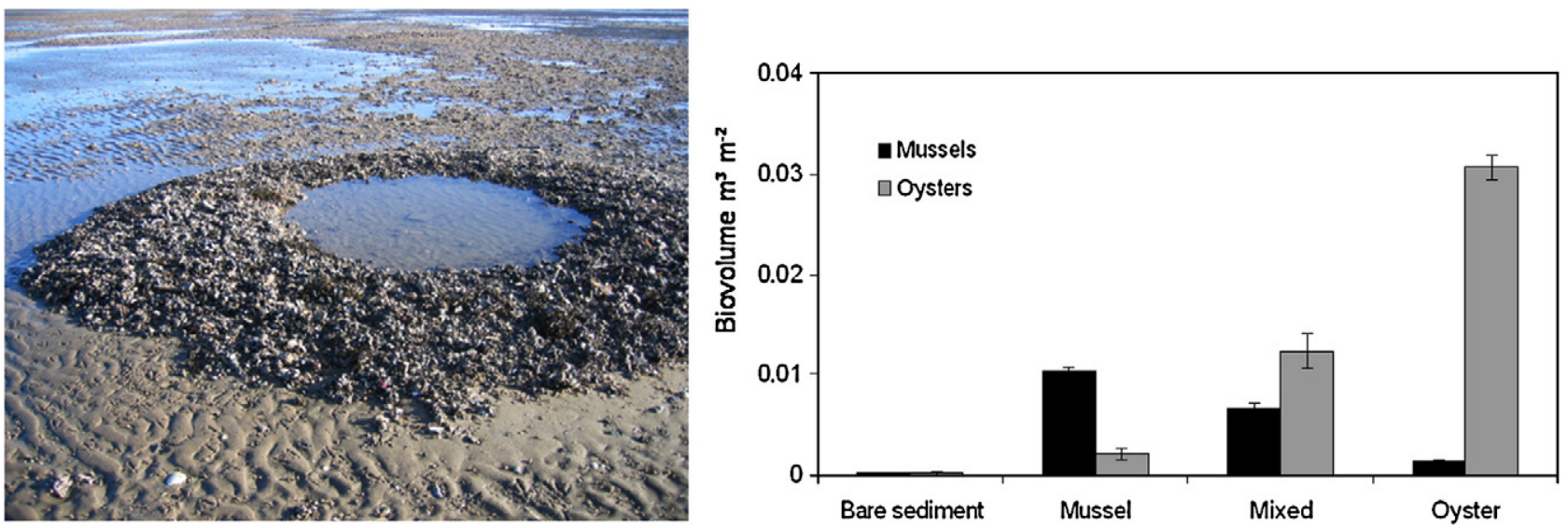

Fig. 3. Experimental plot of $C$. gigas (left) and shellfish volume (right) on plots with epibenthic suspension feeders in June 2006 . Shown are means \pm SE. 


\subsubsection{Epifauna}

Sessile epifauna, i.e. barnacles Semibalanus balanoides (L.), Balanus crenatus (Bruguière), molluscs Lepidochitona cinerea (L.), Crepidula fornicata (L.), polychaetes Polydora ciliata (Johnston), and encrusting algae, were co-transplanted when the experiment was set up. Therefore, we focused on abundance of new recruits during the experimental period and on mobile epifauna assumed to have immigrated in the course of experiment. In particular, we counted recruitment of oysters (ind. $\leq 30 \mathrm{~mm}$ ) and mussels (ind. $\leq 25 \mathrm{~mm}$ ), and the barnacle Elminius modestus (Darwin) (settled in summer 2006) which could be distinguished from older individuals by its shiny whitish colour. Mobile epifauna sufficiently abundant for analysis were the periwinkle Littorina littorea (L.) and the shore crab Carcinus maenas (L.), both of which were present on the ambient tidal flat.

In October 2006 mobile epibenthic macrofauna $(>1 \mathrm{~mm})$ was sampled by randomly placing a frame of $25 \times 25 \mathrm{~cm}\left(625 \mathrm{~cm}^{2}\right)$ on the belt once within each ring covered by suspension feeders or on bare sediment respectively. All organisms encountered above sediment surface were collected. The following size classes were taken into consideration: Carcinus maenas 5 - $10 \mathrm{~mm}$ carapax width, Littorina littorea $<10 \mathrm{~mm}$ and $\geq 10 \mathrm{~mm}$ shell height, Mytilus edulis $\leq 25 \mathrm{~mm}$ and $>25 \mathrm{~mm}$ shell length, Crassostrea gigas $\leq 30 \mathrm{~mm}$ and $>30 \mathrm{~mm}$ of max. shell length.

In March 2007 a smaller frame of $14 \times 14 \mathrm{~cm}\left(\sim 200 \mathrm{~cm}^{2}\right)$ was used. Sampling procedure was similar to October but oysters and mussels were not counted again. The density of Elminius modestus on any kind of hard substratum found inside the frame of $200 \mathrm{~cm}^{2}$ was assessed.

\subsection{Statistical analysis}

All univariate response variables were analysed using generalized linear models (GLM). The maximum models included the factor 'treatment' comprising of 4 levels and the experimental block (unreplicated) that accounted for spatial heterogeneity. For abundance data errors followed in principal a poisson distribution; marginal overdispersion was accounted for by using a quasi-poisson error structure. Proportional response variables such as mud and POM content followed a binomial error-distribution. When overdispersion occurred, again models were fitted using a quasi-binomial error function. All models were simplified to the minimum adequate model (after Crawley, 2005). Resulting significant differences are reported as such and denoted by letters. Data are given as arithmetic means with standard error (SE). The free software R ('R' Development Core Team, 2006) was used to compute generalized linear models.

For studying infaunal species assemblages we applied multivariate statistical techniques (PRIMER Software; Clarke and Warwick, 2001; Plymouth Marine Laboratory). Multi-dimensional scaling (MDS) was based on Bray-Curtis similarity matrices of 2nd-root transformation transformed data to prevent overweighting of abundant species. To detect single species contribution to average Bray-Curtis similarity we used SIMPER procedures within treatments and non-parametric ANOSIM procedures for testing treatment effects on species community structure.

\section{Results}

\subsection{Experimental plots and sediment characteristics}

Mussel rings maintained their shape better than mixed and oyster rings over the observation period from June 2006 to April 2007. Mussels readily became tied up again with their byssal threads after transplantation and thus formed a coherent mat of interconnected mussels. At oyster rings, some individual oysters were found scattered inside or adjacent to rings after rough tides. Oysters had been taken from dense reefs where most were in vertical position with approximately one third of their length anchored in the sediment and stabilized in this position by their neighbors. We were unable to restore original positioning of oysters in the experimental rings. However, after 4 months a vertical positioning of oysters in block 2 to 4 re-emerged, and all rings were still intact after 9 months. Mixed ring performance was intermediate. The seaward edge of rings was most exposed to wave action and more oysters and mussels became dislodged than at the other sides. The bare sediment areas enclosed by the rings of epibenthic suspension feeders were subject to erosion on the seaward side. Part of this eroded sediment became deposited inside the rings on the landward side. Because of this erosion, puddles covered by residual water throughout low tide phase developed inside rings. Mean water depths ( $\mathrm{n}=4$ at each ring) inside oyster belts was $46 \mathrm{~mm}$ and significantly lower than within mixed and mussel belts with 73 and $74 \mathrm{~mm}$ respectively $(\mathrm{p}<0.001)$. This suggests differential potential of mussels and oysters to restrain water and differential effects of both bivalves on near-bottom hydrodynamics and sediment stability.

The presence of filter-feeders induced a significant accumulation of fine particles (Fig. 4). This effect was strongest in the mixed treatments (29\% particles $<63 \mu \mathrm{m}$ ) compared to monospecies treatments (mussel: $17 \%$, oyster: $14 \%$ ) and bare sediment (3\%) and results significantly differed with $\mathrm{p}<0.05$. Organic content did not differ significantly between mussel plots (1.14\%), mixed plots (1.44\%) and oyster plots (1.22\%) but was significantly higher than on bare sediment plots with $0.66 \%$ ( $\mathrm{p}<0.001$, Fig. 4).

\subsection{Infauna}

In total 18 infauna taxa were found at experimental plots in October 2006 and 16 species in March 2007. Most of the infauna taxa were polychaetes (Table 1). The polychaete worms Pygospio elegans Claparède, Spio martinensis Mesnil, Phyllodoce mucosa Ørsted, Nereis virens (Sars), Nephtys sp. and Scoloplos cf. armiger (Müller) mainly occurred on bare sediment. However, treatments had no significant effects on species richness ( $\mathrm{p}>0.05)$.

Total number of individuals (ind.) differed among treatments (Table 1). The total number of individuals, including the dominant $T$. benedeni, was highest on mussel plots (mussels $>$ mixed $>$ oysters $>$ bare sediment). However, oyster belts yielded most individuals when the oligochaete was excluded and were significantly different from other treatments. Lowest numbers always occurred on bare sediment. In October 2006, bare sediment, mussel and mixed treatments did not differ significantly from each other but total individual number was significantly less than in the oyster treatment $(\mathrm{p}<0.01)$. In March 2007, number of individuals on mussel and mixed treatments was $44 \%$ lower than on oyster plots $(\mathrm{p}<0.05)$ and $52 \%$ higher than on bare sediment $(\mathrm{p}<0.05)$.

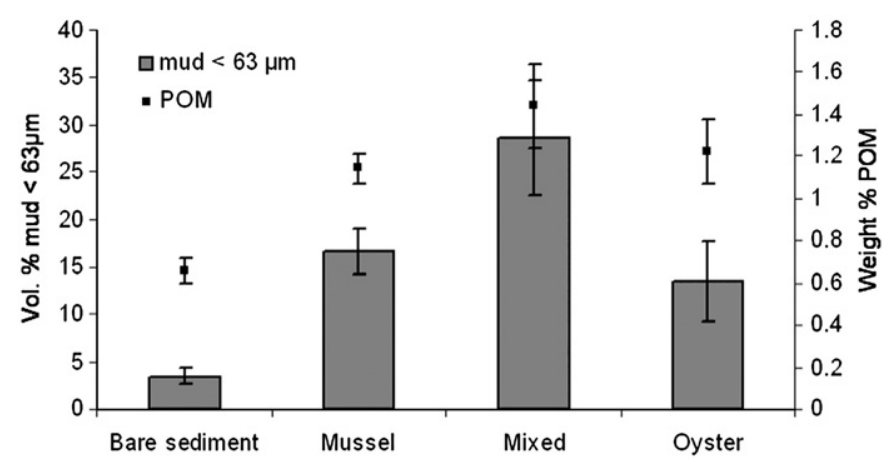

Fig. 4. Distribution of particles $<63 \mu \mathrm{m}$ expressed in volume percentages (left y-axis) and POM expressed in weight percentages (right y-axis) on experimental plots. Shown are means $\pm \mathrm{SE}$. 
Table 1

Infaunal taxa encountered on bare sediment and belts of mussels and oysters in October 2006 and March 2007

\begin{tabular}{|c|c|c|c|c|c|c|c|c|}
\hline & \multicolumn{4}{|l|}{ October 2006} & \multicolumn{4}{|l|}{ March 2007} \\
\hline & Bare sediment & Mussel & Mixed & Oyster & Bare sediment & Mussel & Mixed & Oyster \\
\hline \multicolumn{9}{|l|}{ Nemertea } \\
\hline \multicolumn{9}{|l|}{ Anopla } \\
\hline Lineus ruber & 0 & 0 & 40 & 0 & 0 & 0 & 0 & 0 \\
\hline Lineus viridis & 40 & 0 & 80 & 0 & 0 & 80 & 80 & 40 \\
\hline \multicolumn{9}{|l|}{ Oligochaeta } \\
\hline Tubificoides benedeni & 2320 & 10120 & 5160 & 2160 & 0 & 0 & 0 & 0 \\
\hline Tubificoides sp & 120 & 1840 & 200 & 200 & 0 & 0 & 0 & 0 \\
\hline \multicolumn{9}{|l|}{ Polychaeta } \\
\hline Arenicola marina & 0 & 0 & 0 & 0 & 0 & 10 & 10 & 0 \\
\hline Aricidea sp & 80 & 80 & 0 & 0 & 0 & 0 & 0 & 0 \\
\hline Capitella capitata & 80 & 120 & 80 & 80 & 0 & 50 & 60 & 400 \\
\hline Eumida sanguinea & 0 & 0 & 0 & 0 & 0 & 0 & 0 & 20 \\
\hline Heteromastus filiformis & 0 & 40 & 0 & 40 & 0 & 10 & 20 & 0 \\
\hline Lanice conchilega & 520 & 560 & 480 & 1840 & 240 & 330 & 340 & 560 \\
\hline Malacoceros fuliginosus & 240 & 1320 & 2160 & 1760 & 0 & 590 & 650 & 980 \\
\hline Nepthys sp & 40 & 40 & 0 & 0 & 20 & 0 & 0 & 0 \\
\hline Nereis diversicolor & 0 & 0 & 0 & 0 & 0 & 0 & 0 & 10 \\
\hline Nereis virens & 80 & 40 & 0 & 80 & 20 & 0 & 0 & 0 \\
\hline Phyllodoce mucosa & 0 & 0 & 40 & 80 & 10 & 0 & 0 & 0 \\
\hline Polydora cornuta & 40 & 280 & 160 & 480 & 0 & 0 & 0 & 20 \\
\hline Pygospio elegans & 80 & 0 & 0 & 0 & 0 & 0 & 0 & 0 \\
\hline Scoloplos cf. armiger & 400 & 0 & 0 & 40 & 240 & 10 & 0 & 10 \\
\hline Spio martinensis & 320 & 0 & 0 & 0 & 10 & 0 & 0 & 0 \\
\hline Tharyx killariensis & 0 & 120 & 80 & 0 & 0 & 0 & 0 & 0 \\
\hline \multicolumn{9}{|l|}{ Mollusca } \\
\hline Cerastoderma edule & 40 & 0 & 40 & 80 & 10 & 10 & 0 & 0 \\
\hline Macoma balthica & 40 & 0 & 40 & 40 & 10 & 30 & 30 & 20 \\
\hline Sum of species & 15 & 11 & 10 & 10 & 8 & 8 & 6 & 8 \\
\hline Sum of individuals & 4440 & 14560 & 8560 & 6880 & 560 & 1120 & 1190 & 2060 \\
\hline Sum of individuals excluding oligochaeta & 1960 & 2600 & 3200 & 4520 & 560 & 1120 & 1190 & 2060 \\
\hline
\end{tabular}

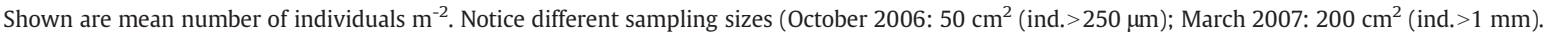

Multivariate analysis indicates a significant effect of epibenthic suspension feeders on the endobenthic assemblages. In MDS plots the bare sediment assemblages clearly separated from assemblages below bivalves (Fig. 5). ANOSIM procedure confirmed that the bare sediment assemblages differed from those on belts with suspension feeders. Separation was strong in March $2007(\mathrm{R}=0.517, \mathrm{p}=0.001)$ and in October $2006(\mathrm{R}=0.341, \mathrm{p}=0.001)$. Overall, there were no differences in the endobenthic community between different epibenthic suspension feeder treatments.

Even with different mesh size used during sampling species mainly contributing to average Bray-Curtis similarity did not change as revealed with by SIMPER procedures. Malacoceros fuliginosus (Claparède) and Lanice conchilega mostly accounted for average similarity within treatments. In bare sediment, the two polychaetes Scoloplos cf. armiger and Spio martinensis also contributed considerably to average similarities.

To investigate responses of the most dominant species to experimental treatments, univariate analysis was applied to the oligochaete $T$. benedeni and the two polychaete species, M. fuliginosus and L. conchilega (Fig. 6). The abundance of the oligochaete T. benedeni was $78 \%$ higher in mussel plots than in bare sediment and oyster plots $(\mathrm{p}<0.001$, Fig. 6 A). Mixed plots had $57 \%$ more individuals of $T$. benedeni than oyster plots and bare sediment $(\mathrm{p}<0.05)$. The spionid polychaete $M$. fuliginosus was absent from the bare sediment in March 2007, and its abundance in suspension feeder belts did not differ significantly (Fig. 6 B). Tube cap abundance of $L$. conchilega was $58 \%$ higher on oyster plots and significantly different to bare sediment, mussel and mixed plots in March 2007 ( $p<0.01$, Fig. 6 C).
October 2006

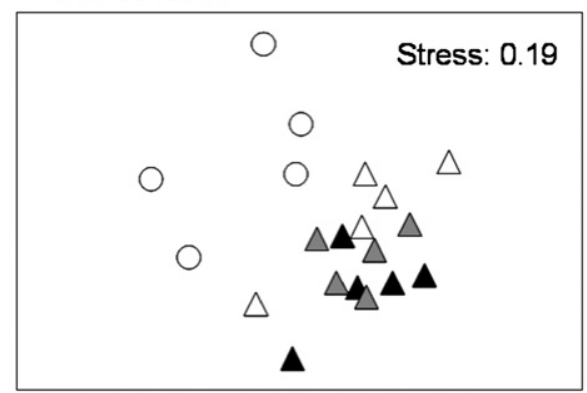

March 2007

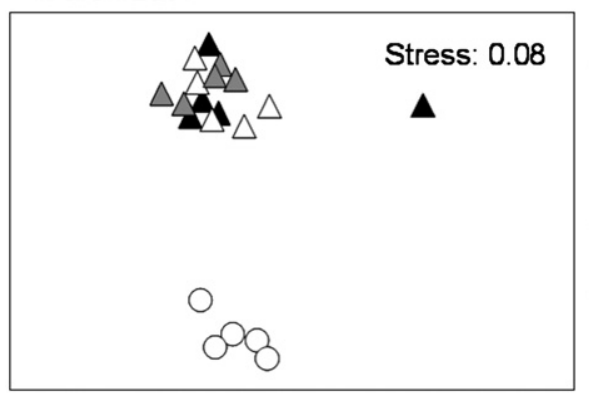

Bare sediment plot

$\Delta$ Mussel plot

$\triangle$ Mixed plot

$\triangle$ Oyster plot

Fig. 5. MDS plots of species assemblages based upon Bray-Curtis similarity matrices of 2nd-root transformed data. Triangles indicate suspension feeder plots. 

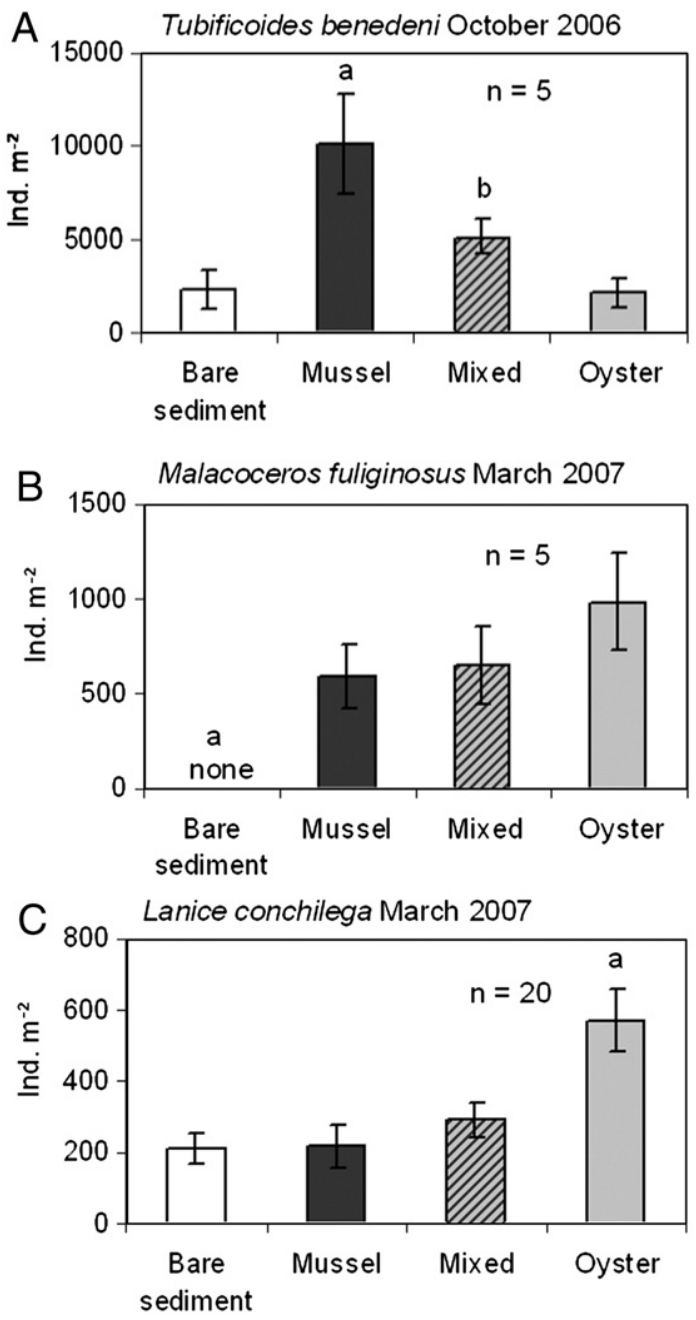

Fig. 6. Mean abundance of infaunal species on experimental plots $( \pm S E)$. Significant differences (after model simplification) are denoted by letters. Tubificoides benedeni in October 2006 (A). Malacoceros fuliginosus in March 2007 (B). Lanice conchilega tube caps in March 2007 (C).

\subsection{Epifauna}

\subsubsection{Recruitment of oysters, mussels and barnacles}

Density of the barnacle Elminius modestus recruits revealed no significant differences between mussel, mixed and oyster plots, but were absent on bare sediment where attachment of recruits was limited by scarcity of substratum (Fig. 7 A).

Oyster recruitment showed a preference for conspecifics. Individuals $\leq 30 \mathrm{~mm}$ were highest on mixed $\left(2602 \pm 301\right.$ ind. $\left.\mathrm{m}^{-2}\right)$ and oyster plots $\left(2627 \pm 349\right.$ ind. $\left.\mathrm{m}^{-2}\right)(\mathrm{p}<0.01$, Fig. 7 B) and were significantly lower on mussel plots $\left(1580 \pm 259\right.$ ind. $\left.\mathrm{m}^{-2}\right)$. On mixed plots the young oysters were mainly attached to adult oysters. On bare sediment the few scattered aggregates of oysters and some shell gravel provided scarcely any substratum for attachment. $M$. edulis $\leq 25 \mathrm{~mm}$ showed no preference for any epibenthic treatment and a significant difference occurred only towards bare sediment ( $p<0.01$, Fig. 7 C). Highest number of mussel recruits was considerably lower (1020 \pm 196 ind. $\mathrm{m}^{-2}$ ) compared to oyster recruits $\left(2627 \pm 349\right.$ ind. $\left.\mathrm{m}^{-2}\right)$ in congeneric treatments respectively.

\subsubsection{Abundance of mobile epifauna}

Mobile epifauna was more abundant in epibenthic bivalve treatments over bare sediment in all cases. Generalized linear models revealed different abundances depending on bivalve identity. In
October, the presence of Mytilus edulis explained the highest abundance of juvenile shore crabs Carcinus maenas (Fig. $8 \mathrm{~A}$ ). Crab densities on oyster plots $\left(365 \pm 70\right.$ ind. $\left.\mathrm{m}^{-2}\right)$ were significantly different from mixed plots $\left(550 \pm 95\right.$ ind. $\left.\mathrm{m}^{-2}\right)$ and mussel plots $\left(742 \pm 127\right.$ ind. $\mathrm{m}^{-2}$ ) $(\mathrm{p}<0.01)$, while $C$. maenas was absent from the bare sediment. In March, abundance of juvenile $C$. maenas showed no preference for any treatment and was almost absent from bare sediment plots with $96 \%$ difference in means $(\mathrm{p}<0.01)$. Fewer numbers occurred on all plots compared to October 2006 (Fig. 8 B) but numbers on oyster plots were not significantly decreased.

Only few juveniles of Littorina littorea were found on bare sediment in October and March (Fig. 8 C - D). In October 2006, juvenile L. littorea $<10 \mathrm{~mm}$ shell height were significantly more abundant on mussel plots ( $3152 \pm 382$ ind. $\mathrm{m}^{-2}$ ) compared to the other epibenthic bivalve treatments $(\mathrm{p}<0.05)$. In March 2007, abundance of small periwinkles differed significantly between all treatments (oysters $>$ mixed $>$ mussels $>$ bare sediment; $\mathrm{p}<0.001$ ) with highest numbers occurring on oyster plots ( $3940 \pm 459$ ind. $\mathrm{m}^{-2}$, Fig. 8 ).

The latter pattern was also observed for larger periwinkles (L. littorea $\geq 10 \mathrm{~mm}$ shell height) which were more abundant on oyster plots in both sampling periods ( $448 \pm 73$ ind. $\mathrm{m}^{-2}$ in October 2006, $590 \pm 87$ ind. $\mathrm{m}^{-2}$ in March 2007; Fig. 8 E - F). Oyster plots were
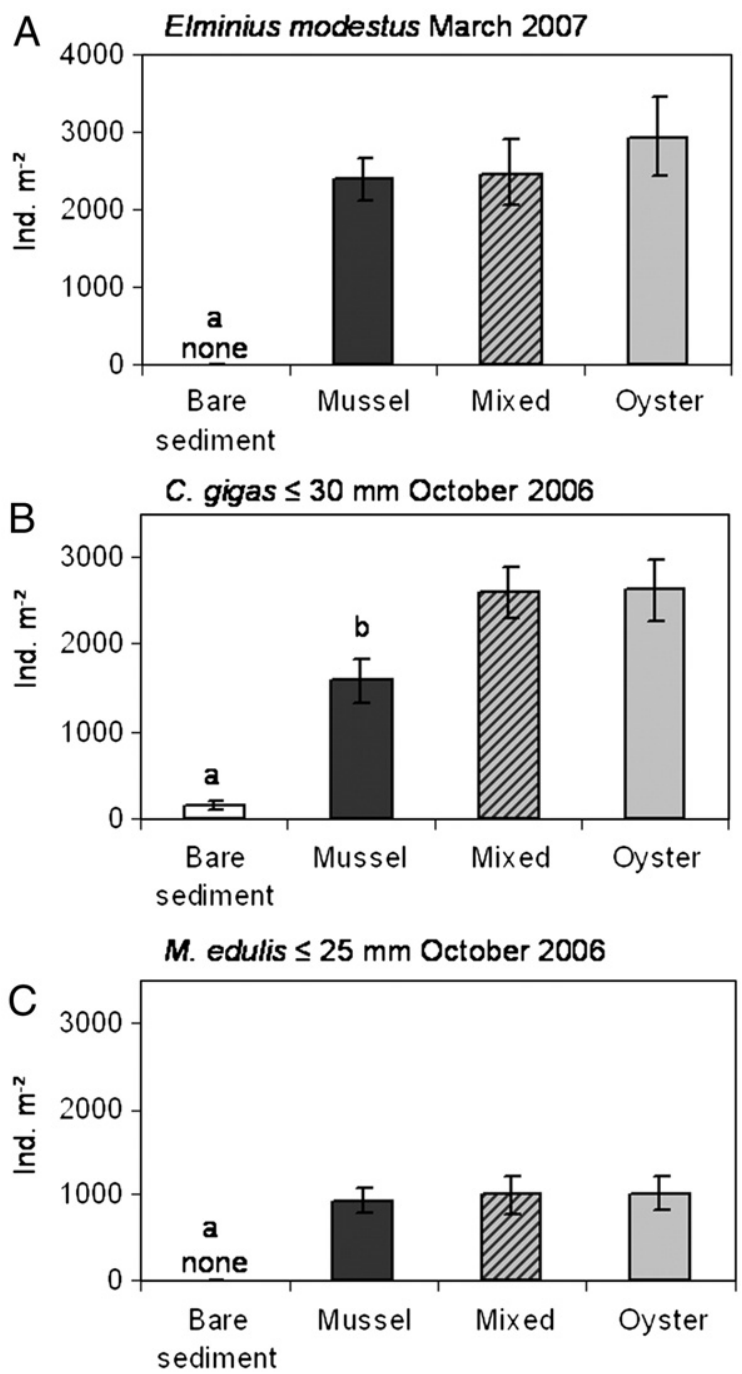

Fig. 7. Mean abundance of recruits on experimental plots $( \pm S E ; n=5)$. Significant differences (after model simplification) are denoted by letters. Elminius modestus in March 2007 (A). Crassostrea gigas $\leq 30 \mathrm{~mm}$ in October 2006 (B). Mytilus edulis $\leq 25 \mathrm{~mm}$ in October $2006(C)$. 

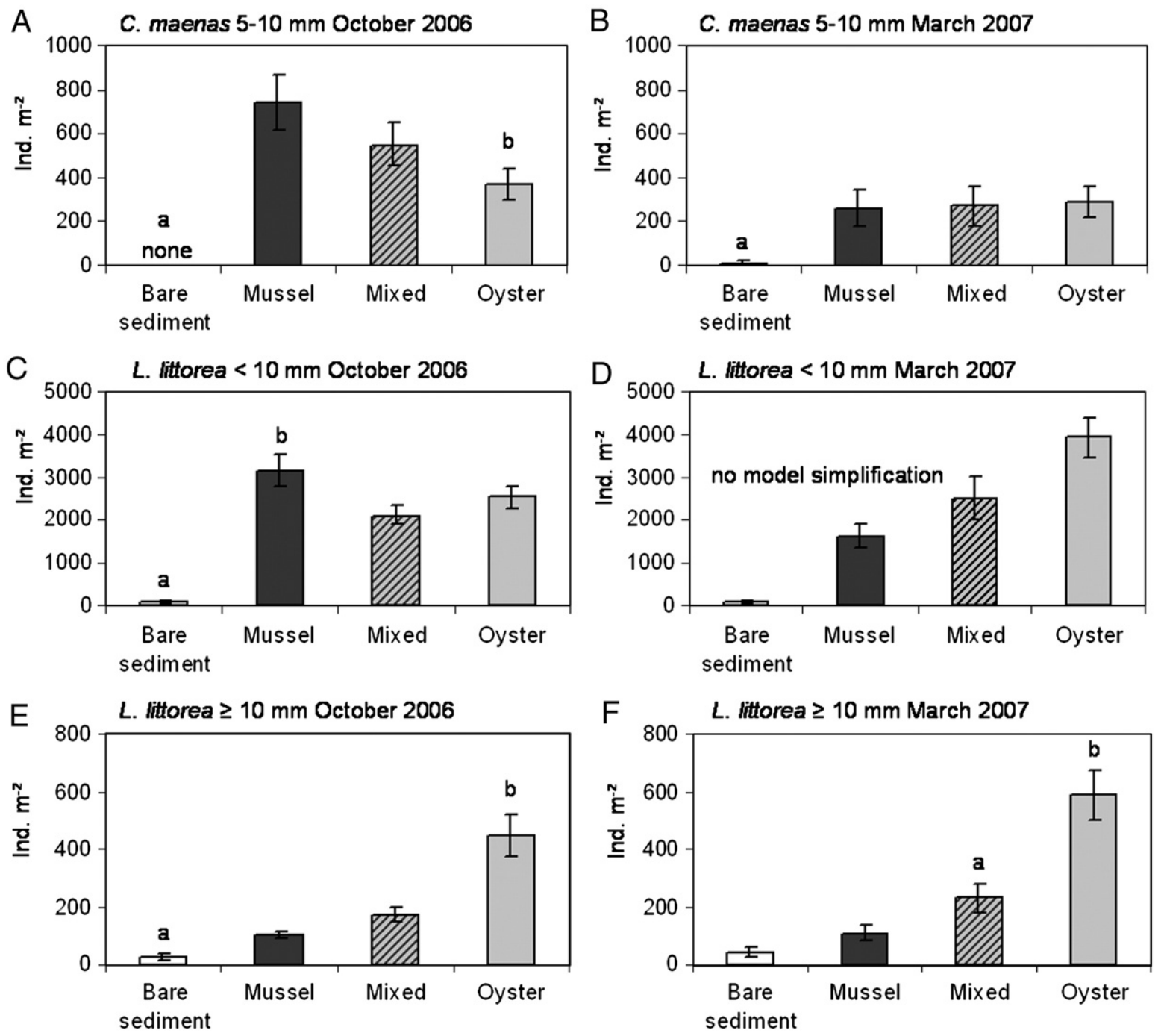

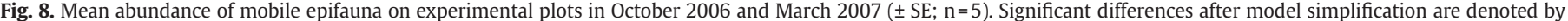

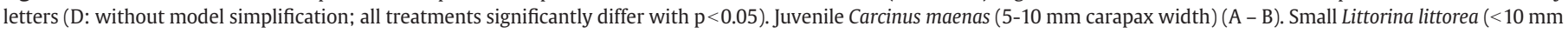
shell height) (C -D). Large Littorina littorea ( $\geq 10 \mathrm{~mm}$ shell height) (E - F).

significantly different from mussel plots ( $102 \pm 11$ ind. $\mathrm{m}^{-2}$ ) and mixed plots $\left(173 \pm 26\right.$ ind. $\left.\mathrm{m}^{-2}\right)$ in October 2006 and also from bare sediment (26 \pm 13 ind. $\mathrm{m}^{-2} ; \mathrm{p}<0.001$ ).

\section{Discussion}

In this study, the two ecosystem engineering bivalves $C$. gigas and M. edulis were tested for their effects on associated macrozoobenthos in an attempt to elucidate the ecosystem impact of the ongoing displacement of mussel beds by Pacific oyster reefs in the Wadden Sea. We approached this subject with a large-scale field experiment in an attempt to simulate naturally occurring habitat structures provided by the resident mussels and the alien oysters. Biogenic structures of the two epibenthic suspension feeders, alone or in combination, differentially altered sediment composition, abundance of an oligochaete and polychaete species, recruitment of oysters and immigration of juvenile shore crabs and of periwinkles.

\subsection{Experimental plots and biogenic habitat structure}

The circular arrangement of belts of suspension feeders was chosen to simulate environments composed of resident mussels, invading oysters or both. Although perfect ring shaped beds are not common they may well serve to simulate the irregular structure generally observed (van de Koppel et al., 2005; Snover and Commito, 1998) and the effects on sediment, associated species and recruitment within the belts are assumed to be representative. Central parts of extensive mussel beds may show some other features (Tsuchiya and Nishihira, 1986; Ragnarsson and Raffaelli, 1999). However, we rarely observe extensive coherent beds of mussels and oysters in the Wadden Sea. Most are elongated and show bare patches similar to the central areas enclosed by our experimental rings.

Mussels are better suited than oysters for transplanting because they quickly reestablish their previous matrix by new byssal connection (Commito and Dankers, 2001). The matrix of oyster beds arises in part by solid attachment of new generations to the shells of previous ones and by adopting an elongated shape with upright positioning in crowded assemblages (own observation). This kind of structure cannot easily be reconstructed with transplanted oysters. Thus, our experimental oyster belts were less dense than natural beds although crowding was the same. This was probably a minor artefact as rings of oysters as well as the mixed and mussel rings basically maintained their shape over a year in spite of a particularly stormy winter in 2006 to 2007. Enhanced mortality was not observed.

Nevertheless, the microtopography of mussel, mixed and oyster rings was distinctly different (Fig. 9). Oysters within belts were 


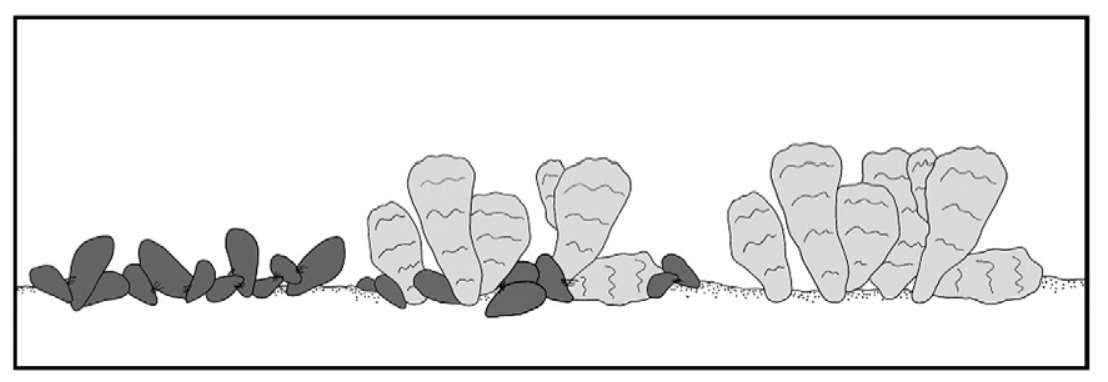

Fig. 9. Illustration of biogenic habitat structures on experimental plots differentially dominated by mussels and oysters; from left to right: mussel plot, mixed plot, oyster plot.

patchier than mussels and with their larger individual sizes and generally upright position they generate more surface roughness than mussels. We hypothesize that surface roughness in particular is crucial for the differential effects of these ecosystem engineers on sediment properties and associated fauna. The dense matrix of mussels, on the other hand, may explain why more fine sediment particles accumulate there compared to the belts of oysters where the sediment remained more similar to that of the bare sediment plots. This interpretation is supported by the observation that less water was retained in central areas of oyster rings compared to mixed and mussel rings. At the densities chosen for this experiment, belts of oysters are more permeable to the flow of water than the other belts and thus, fewer fine sediment particles can settle. Mussels may exhibit larger fractal dimension at intermediate cover (Commito and Rusignuolo, 2000) and then may attain a profile similar to that of Pacific oysters.

The experiment also indicates that there is no linear relationship for the effects of mussels and oysters on their surrounding when arranged in different proportions. The mixed treatment did not always show an intermediate effect. Mussels positioned between the larger oysters may retain more biodeposits of oysters than if oysters occur alone. This is highly important for the Wadden Sea for we may expect continued coexistence in mixed beds (Diederich, 2005). More investigations are needed to determine the production, fate and quality of faeces and pseudofaeces generated by oysters and mussels and how they are retained in monocultures and mixed assemblages.

\subsection{Differential effects on infauna}

As expected from the observed differences in sediment composition, there was a strong effect on infauna by the experimentally arranged suspension feeder belts. In addition to the differences relative to the bare sediment plots, the effects of epibenthic suspension feeders differed in the species composition of attracted infauna, while species richness did not differ. Two mechanisms may explain this phenomenon: (1) differentiated alteration of sediment by the respective epibenthic suspension feeders and (2) differential protection from predation from above or mitigated physical disturbance from wave action by the epibenthic structures.

Predation is assumed to be a key factor. Intertidal flats of the Wadden Sea are nurseries for young epibenthic predators such as flatfish, shrimp and crabs that are capable of significantly reducing infaunal abundances (i.e. Reise, 1985; Strasser, 2002; Beukema and Dekker, 2005). The series of mild winters preceeding the time of our experimental period may have facilitated these predators and their effects on macrozoobenthic recruitment in particular by a temporal match between juveniles of predator and prey. A better accessibility to prey in bare sediment compared to sediment covered with suspension feeders might explain higher infaunal abundances among mussels and oysters. In the same way, accumulation of biodeposits and suspended material as potential food for infaunal species will be facilitated by the epibenthic structures (Crooks, 1998; Commito and Dankers, 2001). On the other hand, the subsurface feeder $S$. cf. armiger, which is highly abundant on sandy intertidal flats in Königshafen outside mussel beds
(Reise et al., 1994), is known to be susceptible to hydrogen sulfide enrichment and decreasing sediment permeability (Kruse et al., 2004; Volkenborn and Reise, 2006). In this study, Scoloplos cf. armiger preferentially occurred in bare sediment plots.

While ANOSIM analysis revealed that the bare sediment assemblage deviated from the other environments, the more subtle differences between mussel, mixed and oyster treatments are particularly apparent by single species analysis. Ecosystem engineering by mussels and oysters facilitated the polychaetes Malacoceros fuliginosus, Lanice conchilega and the oligochaete Tubificoides benedeni. The surface deposit-feeding spionid $M$. fuliginosus was most abundant at epibenthic structures but was indifferent towards bivalve identity. For mussel beds this was previously shown by Dittmann (1990) who observed an increase in abundance of deposit-feeders from bare sandflats to mussel beds. The mainly suspension-feeding $L$. conchilega was most abundant on oyster plots. It might benefit from oyster belts which keep fine particles resuspended near the bottom. Mussels may occasionally be a problematic neighbor because tube caps of $L$. conchilega become entangled in the byssal matrix (own observation). Highest densities of the oligochaete Tubificoides benedeni occurred underneath mussel plots. This might be due to a combination of food enrichment and tolerance to anoxic conditions. This species often thrives well under low oxygen conditions and dominates the fauna of sulfide-rich deoxygenated sediment such as in mussel beds (Commito and Boncavage, 1989).

The singularity of oysters and mussels seem to play an important role affecting infaunal species by various combinations of habitat modifications. The mixed treatment usually exhibited intermediate effects on infauna.

\subsection{Differential effects on epifauna}

The enrichment by shells as a secondary hard substratum and the provision of refugial interspaces was a common feature of the experimental belts of epibenthic suspension feeders. However, the effects on recruiting oysters and on mobile epifauna differed between suspension feeder species and sampling periods. As previously shown by Diederich (2005), juvenile $M$. edulis showed no preference for mussels or oysters, while oyster spat preferentially settled on conspecifics. Similarly, preference of conspecifics was confirmed on mixed plots where most oyster spat settled on adult $C$. gigas rather than on mussels (own observation).

The high recruitment success of oysters in summer 2006 and the positive feedback in settlement will lead to further reef formation in the Wadden Sea. The lack of specificity in mussel recruitment will secure a coexistence of $M$. edulis with the dominant $C$. gigas. Thus, the ring experiment does support the conjecture of Diederich (2005) that resident mussels will not be excluded completely by the invading oysters. Mussels are able to use oyster reefs as a new habitat, and the relative shares of oysters and mussels in these densely packed suspension feeder reefs is likely to depend on the climate regime with differential effects on recruitment (Diederich et al., 2005; Nehls et al., 2006). Warm summers and mild winters facilitating $C$. gigas recruitment while cold winters increase recruitment success of M. edulis. 
Although recruitment of the Australian barnacle Elminius modestus did not differ between the suspension feeder treatments there might be a tendency to prefer oysters. Barnacles preferentially settle on surfaces with cracks and pits (Chabot and Bourget, 1988). Due to their shell structure oysters might provide better available substratum for sessile organisms compared to mussels with smooth and unruffled shells. Barnacle epigrowth is also known to enhance the recruitment of oysters on less favoured mussels and they also increase mussel recruitment on oyster and mussel shells (Buschbaum and Saier, 2001; Diederich, 2005). Thus, barnacle epigrowth may influence recruitment patterns of both bivalve species. As it was not feasible to brush off epibionts of the transferred oysters and mussels composing the $150 \mathrm{~m}^{2}$ of experimental belts, we cannot extend our results to the entire community of sessile epibiota. This needs a different experimental approach.

The distribution patterns of adult $L$. littorea and juvenile $C$. maenas found in this study resemble the situation on mussel and oyster beds in the List tidal basin of 2005 (S. Görlitz, Diplomthesis). There were no significant differences in species richness of mobile epibenthos between sites dominated by oyster and mussels beds but abundances of $C$. maenas and $L$. littorea did change.

In October, the highest abundance of juvenile shore crabs C. maenas (5-10 mm carapax width) occurred on M. edulis plots, while in March these juveniles were spread equally but at lower numbers across the different suspension feeder plots. Mussel clumps are known to constitute a spatial refuge against predation for juvenile shore crabs which might benefit from the dense mussel matrix during their first months of benthic life (Thiel and Dernedde, 1994). We can only speculate why the preference of young shore crabs for belts with mussels compared to belts of oysters was lost from autumn to spring. Additional experiments are needed to reveal whether this is caused by changing food availability or a different predation pressure on the crabs. However, oyster reefs seem to constitute an alternative habitat for juvenile shore crabs. Interestingly, in March 2007, densities of juvenile $C$. maenas had only decreased on mussel and mixed plots. Thus, there might be density dependence of juvenile $C$. maenas with regard to refuges. Accordingly, when total abundance was high in October 2006, mussel and mixed plots may provide more refuges for juvenile shore crabs than oyster plots where potential refuges are more limited.

The experimental results on small and large periwinkles seem to reveal ontogenetic and/or seasonal shifts in habitat preference between rings of mussels and oysters. Large shore crabs preferentially attack small to medium sized periwinkles (Hadlock, 1980; Buschbaum et al., 2007) but leave the tidal zone of Königshafen to overwinter subtidally (Reise, 1985; Thiel and Dernedde, 1994). A more intricate matrix of interconnected mussels is suggested to provide a better refuge from adult crabs in October as compared to a coarser matrix of the large oysters. In March adult crabs have not yet returned from their subtidal overwintering sites, and small and large periwinkles distribute more according to food availability rather than predator refuge. Thus, we further suggest that oyster belts with their large biovolume supply more surface area to feed on microbial films than do mussels. This could explain why in autumn only the larger $L$. littorea were more abundant on oysters, while in March both, small and large periwinkles were taking advantage of the oyster habitat. More experiments are required to explore the subtle roles of habitat structures with respect to bottom-up and top-down effects on periwinkles.

\subsection{Conclusion}

The ring experiment has shown that biogenic habitat change from resident mussel beds to novel oyster reefs does not constitute a threat to species diversity but causes a shift in abundance of dominant associated species. Mussels and oysters may be functionally equivalent as consumers. However, the epibenthic biogenic structures they generate seem to unfold subtle differences in habitat properties. Their community effects can only be explained in the context of the ecological web of species interactions. The differences in infauna and epifauna on mussel, mixed and oyster belts will have implications on foraging birds as well as on the relative proportions between mussels and oysters in the intertidal Wadden Sea in the years to come.

\section{Acknowledgements}

Several hands helped in setting up the field experiment but we want to thank in particular Patrick Polte, Kay von Böhlen and Alfred Resch for their strenuous support. We also thank Till Eggers for his advice on statistical analysis and Christian Hass and Tobias Dolch providing assistance with sediment analysis. The first author is grateful to Erik Kristensen supervising her thesis. We acknowledge the support by the MARBEF network of excellence "Marine Biodiversity and Ecosystem Functioning" which is funded in the Community`s Sixth Framework Programme (contract no. GOCE-CT-2003-505446). [SS]

\section{References}

Austen, I., 1994. The surficial sediments of Königshafen - variations over the past 50 years. Helgol. Meeresunters. 48, 163-171.

Beukema, J.J., Dekker, R., 2005. Decline of recruitment success in cockles and other bivalves in the Wadden Sea: possible role of climate change, predation on postlarvae and fisheries. Mar. Ecol. Prog. Ser. 287, 149-167.

Blott, S.J., Pye, K., 2001. GRADISTAT 4.0: A grain size distribution and statistics package for the analysis of unconsolidated sediments. Earth Surf. Process. Landf. 26, $1237-1248$

Buschbaum, C., Saier, B., 2001. Growth of the mussel Mytilus edulis L. in the Wadden Sea affected by tidal emergence and barnacle epibionts. J. Sea. Res. 45, 27-36.

Buschbaum, C., Chapman, A.S., Saier, B., 2006. How an introduced seaweed can affect epibiota diversity in different coastal systems. Mar. Biol. 148, 743-754.

Buschbaum, C., Buschbaum, N., Schrey, I., Thieltges, D.W., 2007. Shell-boring polychaetes affect gastropod shell strength and crab predation. Mar. Ecol. Prog. Ser. 329, 123-130.

Chabot, R., Bourget, E., 1988. Influence of substratum heterogeneity and settled barnacle density on the settlement of cypris larvae. Mar. Biol. 97, 45-56.

Clarke, K.R., Warwick, R.M., 2001. Change in marine communities: an approach to statistical analysis and interpretation, 2nd ed. PRIMER-E, Plymouth.

Commito, J.A., Boncavage, E.M., 1989. Suspension-feeders and coexisting infauna an enhancement counterexample. J. Exp. Mar. Biol. Ecol. 125, 33-42.

Commito, J.A., Dankers, N.M.J.A., 2001. Dynamics of spatial and temporal complexity in European and North American soft-bottom mussel beds. In: Reise, K. (Ed.), Ecological Comparisons of Sedimentary Shores. Springer, Berlin, pp. 39-59.

Commito, J.A., Dow, W.E., Grupe, M., 2006. Hierarchical spatial structure in soft-bottom mussel beds. J. Exp. Mar. Biol. Ecol. 330, 27-37.

Commito, J.A., Rusignuolo, B.R., 2000. Structural complexity in mussel beds: the fractal geometry of surface topography. J. Exp. Mar. Biol. Ecol. 255, 133-152.

Crawley, M.J., 2005. Statistics. An introduction using R. John Wiley, New York.

Crooks, J.A., 1998. Habitat alteration and community-level effects of an exotic mussel, Musculista senhousia. Mar. Ecol. Prog. Ser. 162, 137-152.

Crooks, J.A., 2002. Characterizing ecosystem-level consequences of biological invasions: the role of ecosystem engineers. Oikos 97, 153-166.

Cuddington, K., Hastings, A., 2004. Invasive engineers. Ecol. Model. 178 (3-4), 335-347.

Diederich, S., 2005. Differential recruitment of introduced Pacific oysters and native mussels at the North Sea coast: coexistence possible? J. Sea. Res. 53, 269-281.

Diederich, S., 2006. High survival and growth rates of introduced Pacific oysters may cause restrictions on habitat use by native mussels in the Wadden Sea. J. Exp. Mar. Biol. Ecol. 328, 211-227.

Diederich, S., Nehls, G., van Beusekom, J.E.E., Reise, K., 2005. Introduced Pacific oysters (Crassostrea gigas) in the Northern Wadden Sea: Invasion accelerated by warm summers? Helgol. Mar. Res. 59, 97-106.

Dittmann, S., 1990. Mussel beds - amensalism or amelioration for intertidal fauna? Helgol. Meeresunters. 44, 335-352.

Gätje, C., Reise, K., 1998. Ökosystem Wattenmeer, Austausch-, Transport-, und Stoffumwandlungsprozesse. Springer, Berlin.

Görlitz, S. 2005. Neue Roiffe im Wattenmeer: Die Pazifische Auster Crassostrea gigas und ihre assoziierte Lebensgemeinschaft. University of Kiel, Diplomthesis.

Hadlock, R.P., 1980. Alarm response of the intertidal snail Littorina littorea (L.) to predation by the crab Carcinus maenas (L.). Biol. Bull. 159, 269-279.

Jones, C.G., Lawton, J.H., Shachak, M., 1994. Organisms as ecosystem engineers. Oikos 69, 373-386.

Kostylev, V., Erlandsson, J., 2001. A fractal approach for detecting spatial hierarchy and structure on mussel beds. Mar. Biol. 139, 497-506.

Kruse, I., Strasser, M., Thiermann, F., 2004. The role of ecological divergence in speciation between intertidal and subtidal Scoloplos armiger (Polychaeta, Orbiniidae). J. Sea. Res. 51, 53-62.

Lenihan, H.S., 1999. Physical-biological coupling on oyster reefs: How habitat structure influences individual performance. Ecol. Monogr. 69 (3), 251-275. 
Nehls, G., Diederich, S., Thieltges, D., Strasser, M., 2006. Wadden Sea mussel beds invaded by oysters and slipper limpets: competition or climate control? Helgol. Mar. Res. 60, 135-143.

Rabaut, M., Guilini, K., van Hoey, G., Vincx, M., Degraer, S., 2007. A bio-engineered softbottom environment: The impact of Lanice conchilega on the benthic speciesspecific densities and community structure. Estuar. Coast. Shelf Sci. 1-12.

Ragnarsson, S.A., Raffaelli, D., 1999. Effects of the mussel Mytilus edulis L. on the invertebrate fauna of sediments. J. Exp. Mar. Biol. Ecol. 241, 31-43.

R Development Core Team, 2006. R: A language and environment for statistical computing. R Foundation for Statistical Computing, Vienna, Austria. URL http:// www.R-project.org.

Reise, K., 1985. Tidal Flat Ecology. Springer, Berlin.

Reise, K., 1998. Pacific oysters invade mussel beds in the European Wadden Sea. Senckenb. marit. 28, 167-175.

Reise, K., 2002. Sediment mediated species interactions in coastal waters. J. Sea. Res. 48, 127-141.

Reise, K., Herre, E., Sturm, M., 1994. Biomass and abundance of macrofauna in intertidal sediments of Königshafen in the northern Wadden Sea. Helgol. Meeresunters. 48, 201-215.

Snover, M.L., Commito, J.A., 1998. The fractal geometry of Mytilus edulis L. in spatial distribution in a soft-bottom system. J. Exp. Mar. Biol. Ecol. 223, 53-64.

Strasser, M., 2002. Reduced epibenthic predation on intertidal bivalves after a severe winter in the European Wadden Sea. Mar. Ecol. Prog. Ser. 241, 113-123.
Strasser, M., Reinwald, T., Reise, K., 2001. Differential effects of the severe winter of 1995/ 96 on the intertidal bivalves Mytilus edulis, Cerastoderma edule and Mya arenaria in the Northern Wadden Sea. Helgol. Mar. Res. 55, 190-197.

Thiel, M., Dernedde, T., 1994. Recruitment of shore crabs Carcinus maenas on tidal flats: mussel clumps as an important refuge for juveniles. Helgol. Mar. Res. 48, 321-332.

Thieltges, D.W., Strasser, M., Reise, K., 2006. How bad are invaders in coastal waters? The case of the American slipper limpet Crepidula fornicata in Western Europe. Biological Invasions 8, 1673-1680.

Tsuchiya, M., Nishihira, M., 1986. Islands of Mytilus edulis as a habitat for small intertida animals: effect of Mytilus age structure on the species composition of the associated fauna and community organization. Mar. Ecol. Prog. Ser. 31, 171-178.

van de Koppel, J., Rietkerk, M., Dankers, N., Herman, P.M.J., 2005. Scale-dependent feedback and regular spatial patterns in young mussel beds. Am. Nat. 165, E66-E77.

van Hoey, G., Vincx, M., Degraer, S., 2006. Some recommendations for an accurate estimation of Lanice conchilega density based on tube counts. Helgol. Mar. Res. 60, 317-321.

Volkenborn, N., Reise, K., 2006. Lugworm exclusion experiment: Responses by depositfeeding worms to biogenic habitat transformations. J. Exp. Mar. Biol. Ecol. 330, 169-179.

Wallentinus, I., Nyberg, C.D., 2007. Introduced marine organisms as habitat modifiers. Mar. Poll. Bull. 55, 323-332. 